\title{
Химические лабораторные реакторы высокого давления: основные характеристики и области применения
}

Н. А. Петушков, "Веталайн», Санкт-Петербург

УДК 66.02 info@vetaline.ru

\begin{abstract}
Описаны характеристики химических реакторов высокого давления двух типов: традиционной конструкции и с применением сверхкритической флюидной экстракции. Обсуждаются их возможности и области применения, отмечены преимущества реакторов второго типа. Приведены примеры практического использования в различных приложениях. Особое внимание уделено мерам безопасности и автоматизации процесса экстракции.
\end{abstract}

\section{ХИМИЧЕСКИЙ РЕАКТОР ВЫСОКОГО ДАВЛЕНИЯ HPR}

HPR-серия химических реакторов производства компании Supercritical fluid technologies, INC предназначена для изучения возможностей химических реакций под давлением, получения необходимых продуктов в лабораторных условиях, а также синтеза различных материалов для исследования, анализа и разработки новой продукции.

Лабораторный реактор высокого давления, как правило, состоит из реакционного сосуда от 50 мл до 4 л, оснащенного соответствующими модулями добавления растворяющего средства $\left(\mathrm{CO}_{2}\right.$, жидкостью или газом) и реагентов, контроллеров смешивания, нагрева / охлаждения, оборудованием системы безопасности, расходомера, датчиков и контроллеров расхода (рис. 1). Типовой рабочий режим: давление до 10000 psi (68,9 МПа), температура до $350^{\circ} \mathrm{C}$

Полученные в результате тестирования возможностей лабораторного реактора данные и образцы веществ могут быть использованы для оценки качества конечного продукта и изучения таких технологических параметров, как:

- $\quad$ растворяющая способность реагентов;

- условия реакции (температура, давление, использование сорастворителей для усиления определенных свойств реагентов);

- условия пробоотбора.

Реакторы высокого давления оснащены магнитными спаренными импеллерами для оптимального смешивания.
Все компоненты совместимы и защищены разрывным диском для безопасной работы. Опционально для работы с реакторами HPR-серии, можно добавить окно для сосуда с нагревом до $150^{\circ} \mathrm{C}$, дополнительные порты, катушки охлаждения, пробоотборные петли, экраны и модули для дозировки реагентов.

Лабораторные модели настольного типа идеальны для приложений, где необходимы повторяющиеся функции: каталитические исследования, полимеризация, гидрогенизация, окисление, изомеризация и дегидрирование.

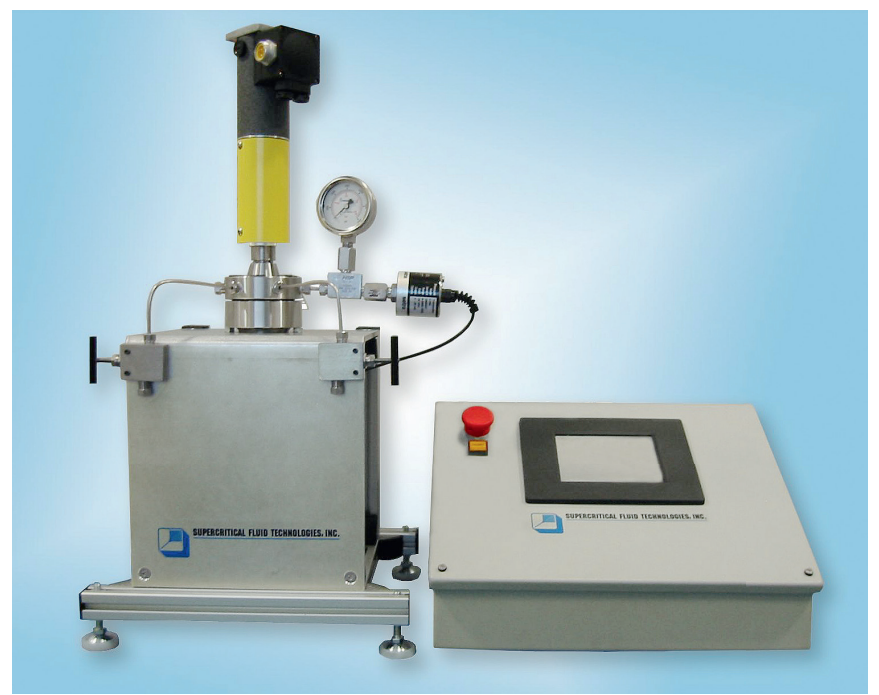

Puc. 1. Химический реактор высокого давления HPR-серии 
Химические реакторы довольно компактны, могут легко помещаться в вытяжной шкаф. Модульная конструкция позволяет легко сменять необходимые детали, экономически эффективна и легко адаптируется для решения новых задач.

Все функции управляются встроенным процессором с многофункциональным цветным ЖК-сенсорным экраном: контроль температуры в закрытом реакторе, скорость смешения, индикация и контроль давления, контроль от перегрева или отклонения от заданных параметров, программирование линейного изменения и выдержки температуры и скорости смесителя. RS-232 порт предоставляет возможность экспортировать данные на внешний компьютер. USB2.0-интерфейс предоставляет возможность записи на флеш-накопитель без Пк.

Области применения реакторов высокого давления HPR: алкилирование, аминирование, биотехнологии, карбоксилирование, каталитическое восстановление, ферментация, галогенирование, гидролиз, изомеризация, нитрование, оксидирование, полимеризация, гидрирование и дегидрирование, обработка токсичных и опасных веществ.

\section{СИСТЕМА СВЕРХКРИТИЧЕСКОЙ ФЛЮИДНОЙ ЭКСТРАКЦИИ SFT-250}

Типичная СФЭ-система состоит из реакционного сосуда от 50 мл до 4 л, оснащенного соответствующими модулями для добавления реагентов, контроллеров смешивания, нагрева / охлаждения, температуры, оборудования системы безопасности, расходометра, датчиков и контроллеров расхода. Увеличенный сосуд (в модели SFT-250 до 5 л) предназначен для экстракции из больших объемов сыпучих материалов (рис. 2). Высокая производительность системы SFT-250 достигается благодаря воздушному насосу, который создает необходимое для сверхкритической экстракции высокое давление; стандартный расход жидкого $\mathrm{CO}_{2}$ от 1 до 330 мл / мин (250 г/ мин).

Безопасность имеет первостепенное значение во всех системах. Электронная сигнализация предупреждает пользователя о перегреве и чрезмерном давлении. В качестве дополнительной меры используется разрывной диск для механической защиты от чрезмерного давления. Съемные боковые и передние панели позволяют быстро добраться до сосудов высокого давления, клапанов, фитингов и электроники. Ручные клапаны обеспечивают длительный срок службы системы.

Для добавления сверхкритической жидкости в реакционную систему обычно используется специальный насос высокого давления. Реагенты можно поместить в реакционный сосуд высокого давления, а потоки углекислого газа и вещества, участвующего в реакции - в реактор. Микроклапан снижает давление сверхкритической жидкости (до газообразного состояния) и продукт реакции собирается непосредственно из реакционного сосуда. Таким способом

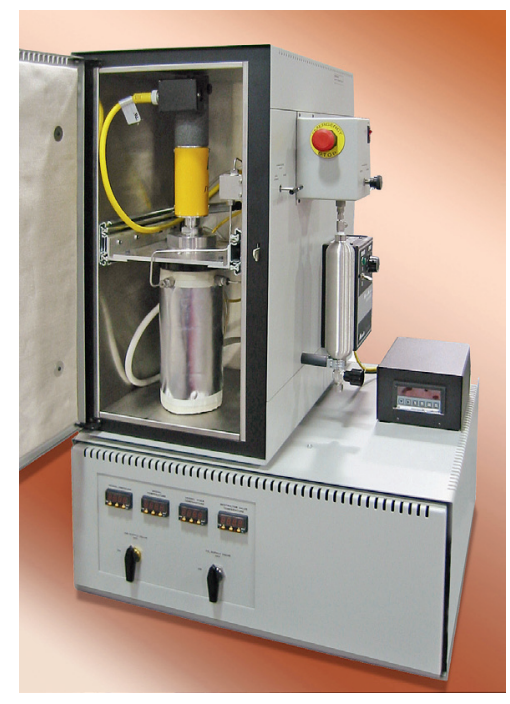

Puc. 2. Система

сверхкритической

флюидной экстракции SFT-250

можно изучать ключевые реакционные параметры обработки для оптимизации технологического выхода и качества целевого продукта.

Подготовка реагента к экстракции состоит из следующих этапов: определение способности растворяться в сверхкритической жидкости, просеивание, измельчение, расслаивание, паллетизация, сушка и смачивание. Далее устанавливаются параметры реакции: давление, температура, выбор растворителя, выбор сорастворителя (концентрации), расход, соотношение сторон сосуда, отношение растворитель/сырье, конфигурация смешивания.

Когда давление и температура растут, на промежуточных этапах можно извлекать целевой компонент для дальнейшего разделения и получения чистого продукта. На всех стадиях работает сепаратор, параметры которого также настраиваются: давление, температура, сепарация абсорбента, мембранная сепарация, фильтрационная сепарация, центробежная сепарация, фракционное разделение.

$$
\because ;: ;
$$

Использование реакции высокого давления, как для традиционных растворителей, так и для сверхкритической жидкости дает возможность ограничить или заменить применяемые обычно токсичные органические растворители и одновременно оптимизировать и точно контролировать воздействие растворителя на выход реакции. В отличие от обычных растворителей сверхкритические жидкости меняют свойства при изменении давления, переходя из газоподобного в жидкоподобное состояние и наоборот. Меняется их растворяющая способность и плотность, от которой зависят такие характеристики участвующих в реакции веществ, как диэлектрическая проницаемость, вязкость, коэффициент диффузии и др. Кроме того, контроль растворяющей способности посредством давления создает возможность облегченной сепарации продуктов и катализаторов, как от традиционных растворителей, так и от сверхкритических. 